\title{
Physiology of the mixotrophic dinoflagellate Fragilidium subglobosum. I. Effects of phagotrophy and irradiance on photosynthesis and carbon content
}

\author{
Alf Skovgaard ${ }^{1, *}$, Per J. Hansen ${ }^{1}$, Diane K. Stoecker ${ }^{2}$ \\ ${ }^{1}$ Marine Biological Laboratory, University of Copenhagen, Strandpromenaden 5, 3000 Helsingør, Denmark \\ ${ }^{2}$ University of Maryland Center for Environmental Science, Horn Point Laboratory, PO Box 775, Cambridge, \\ Maryland 21613, USA
}

\begin{abstract}
Photosynthesis was measured for the mixotrophic dinoflagellate Fragilidium subglobosum grown with and without prey (Ceratium lineatum), at 5 different irradiances. Photosynthetic rates were measured in phototrophically and mixotrophically grown cultures by use of the single-cell ${ }^{14} \mathrm{C}$ uptake technique. Photosynthetic rates were reduced by 48 to $69 \%$ and cellular chlorophyll a (chl a) content was reduced by 13 to $67 \%$ in food-replete mixotrophic cultures as compared with strictly phototrophic cultures grown at the same irradiances. Under the same conditions, chl anormalized photosynthetic rates were thus 7 to $49 \%$ lower in mixotrophic cultures than in strictly phototrophic cultures. It is, therefore, suggested that either the photosynthetic apparatus becomes less efficient when the cells are phagotrophically active or the chl a-normalized photosynthesis is reduced because fed cells contain photosynthetically inactive chl $a$ in their food vacuoles. When food is abundant, the greater part of the gross carbon uptake of $F$. subglobosum is acquired through phagotrophy even at irradiances saturating for photosynthesis.
\end{abstract}

KEY WORDS: Mixotrophy $\cdot$ Dinoflagellate $\cdot$ Photosynthesis $\cdot$ Single-cell ${ }^{14} \mathrm{C}$ technique $\cdot$ Chlorophyll $a \cdot$ Ingestion $\cdot \mathrm{C}$ content $\cdot \mathrm{N}$ content $\cdot \mathrm{C}$ budget

\section{INTRODUCTION}

Since the discovery of widespread phagotrophy among phytoflagellates and the realization that they are sometimes important grazers in plankton (e.g. Bird \& Kalff 1986, 1987, Sanders et al. 1989, Bockstahler \& Coats 1993, Hall et al. 1993), increasing attention has been directed towards the biology and physiology of these mixotrophs (e.g. Andersson et al. 1989, Caron et al. 1990, Caron et al. 1993, Skovgaard 1996a, Stoecker et al. 1997). Most existing studies of phagotrophic phytoflagellates have concentrated on their heterotrophic capabilities, i.e. the relative importance of feeding for survival and growth, and the influence

*E-mail: alfmbl@vip.cybercity.dk thereon of biotic and abiotic factors. Light has been shown to have different effects on feeding activity in different species, varying from stimulation (Caron et al. 1993) to inhibition of feeding (Jones et al. 1993), but the effect of light on feeding can also be more complex (Skovgaard 1996a), or in some cases negligible (Andersson et al. 1989, Sanders et al. 1990, Jeong et al. 1999) .

Feeding in turn may affect photosynthesis, but so far only few investigations have dealt with this aspect ( $\mathrm{Li}$ et al. 1999). A few studies have shown an effect of feeding on cellular chlorophyll a (chl a) content, which should be closely linked to an effect on photosynthesis. Interspecific differences in the effect of feeding on chl $a$ are large. In some species, the cellular chl a content decreases as a response to feeding (Sanders et al. 1990, Holen \& Boraas 1995, Skovgaard 1996a), 
whereas in other species feeding seems to have no or even a positive effect on the chl a content (Jones et al. 1995, Li et al. 1999).

In the mixotrophic dinoflagellate Fragilidium subglobosum feeding has been shown to cause a decrease in cellular chl a content (Skovgaard 1996a). F. subglobosum is a facultative mixotroph which preys selectively on species of another dinoflagellate genus, Ceratium (Skovgaard 1996b). It is able to grow phototrophically in monoculture as well as strictly heterotrophically, but the maximum growth rate is obtained through mixotrophic growth (Skovgaard 1996a, Hansen \& Nielsen 1997). However, mixotrophic growth of $F$. subglobosum is not as rapid as the sum of the independent phototrophic and phagotrophic growth rates would suggest (Skovgaard 1996a). It thus seems that feeding has a negative effect on photosynthesis or, alternatively, that photosynthetic activity causes heterotrophic efficiency to decrease. In this paper we test how photosynthesis in F. subglobosum is affected by phagotrophy and whether such an effect is dependent on irradiance. Ingestion rates in terms of the number of prey cells ingested by F. subglobosum have previously been shown to depend on irradiance (Skovgaard 1996a). By measuring cellular C content, we also studied whether ingestion rates in terms of amount of prey $\mathrm{C}$ ingested is likewise dependent on irradiance and a budget of phototrophic and phagotrophic $\mathrm{C}$ acquisition by $F$. subglobosum is established. In a second paper (Hansen et al. 2000, in this issue) we focus on photosynthesis and chl a content of $F$. subglobosum during the transitions between phototrophic and mixotrophic growth as well as at different prey concentrations.

\section{MATERIALS AND METHODS}

General experimental conditions. Stock cultures of the dinoflagellates Fragilidium subglobosum (v. Stosch) Loeblich and Ceratium lineatum (Ehrenberg) Cleve were established on cells isolated from the Kattegat, Denmark (Skovgaard 1996b, Hansen \& Nielsen 1997). They were grown non-axenically in B-medium (Hansen 1989) based on autoclaved seawater (30 psu, $\mathrm{pH}=8.0$ to 8.2 ) at $\mathrm{ca} 15^{\circ} \mathrm{C}$ in dim light (ca $20 \mu \mathrm{E}$ $\mathrm{m}^{-2} \mathrm{~s}^{-1}$ ).

Prior to experiments, cultures were acclimated to various irradiances for $>7 \mathrm{~d}$ in order to obtain close to steady-state conditions. Mixotrophic cultures were acclimated for another $\geq 5 \mathrm{~d}$ with food added $(\geq 800$ Ceratium lineatum $\mathrm{ml}^{-1}$, Skovgaard 1996a, Hansen et al. 2000). Concentrations of Fragilidium subglobosum in these cultures were low (10 to 100 cells ml-1) to ensure that they were in exponential growth phase (data not shown). Cultures were acclimated in $62 \mathrm{ml}$ polystyrene bottles mounted on a vertically rotating plankton-wheel (1 rpm), which was illuminated from 1 direction by cool white fluorescent tubes at a light:dark cycle of 16:8 h. A water-cooled plankton-wheel was used for the higher light intensities $\left(>50 \mu \mathrm{E} \mathrm{m}^{-2} \mathrm{~s}^{-1}\right)$ to prevent heating due to the light. Temperature was thereby kept at $15 \pm 1^{\circ} \mathrm{C}$ during all experiments and acclimation periods. Irradiance, I (photosynthetically active radiation), was measured outside the culture vessels with a Li-Cor LI-192SA radiation sensor connected to a Li-Cor LI-1000 data logger (Li-Cor Inc., Lincoln, NE, USA).

Photosynthesis. The prey Ceratium lineatum is a photosynthetic organism, and it was therefore necessary to separate predators from prey prior to photosynthesis measurements. Inspired by Rivkin \& Seliger (1981) and Stoecker et al. (1988), this was done by picking individual Fragilidium subglobosum cells with a drawn-out Pasteur pipette and rinsing each cell in Whatmann GF/F-filtered B-medium. The cells were then transferred to $20 \mathrm{ml}$ capacity glass scintillation vials containing $2 \mathrm{ml}$ freshly GF/F-filtered B-medium. A NaH ${ }^{14} \mathrm{CO}_{3}$ stock solution was added (specific activity $=100 \mu \mathrm{Ci} \mathrm{ml}{ }^{-1}$, Carbon 14 Centralen, Denmark), resulting in a specific activity of $\sim 1.0 \mu \mathrm{Ci} \mathrm{ml}{ }^{-1}$, and the vials were incubated without agitation for $3 \mathrm{~h}$ (see below) starting 1 to $3 \mathrm{~h}$ after onset of the light period. The vials were always accompanied by parallel dark vials, which were treated likewise but wrapped in aluminum foil during incubation. After incubation, specific activity of the medium was checked by transferring $100 \mu \mathrm{l}$ from each vial to new vials containing $200 \mu \mathrm{l}$ phenylethylamine. The amount of fixed ${ }^{14} \mathrm{C}$ was measured in the remaining $1.9 \mathrm{ml}$, which received $2.0 \mathrm{ml}$ of $10 \%$ glacial acetic acid in methanol to remove all inorganic $\mathrm{C}$. These vials were dried overnight at $60^{\circ} \mathrm{C}$, and then the residue was re-dissolved in $2 \mathrm{ml}$ of distilled water. Finally, $10 \mathrm{ml}$ of Packard Insta-Gel Plus scintillation cocktail were added to all vials, new caps (Packard poly screw caps) were mounted and activities were determined with a Packard 1500 Tri-Carb liquid scintillation analyzer with automatic quench correction. (The replacement of caps before scintillation counting was important in order to obtain reliable, low dark-vial activities, i.e. 30 to 70 disintegrations $\mathrm{min}^{-1}$ [dpm] vial ${ }^{-1}$. If the caps were not replaced, dark-vial activities were variable and could reach values up to 2-400 dpm vial ${ }^{-1}$.) Calculation of photosynthetic rates, $P$, were based on the equation given by Parsons et al. (1984). Dissolved inorganic carbon content was measured with a type 225-Mk3 infrared gas analyzer (Analytic Development Co. Ltd, Hoddesdon, England).

Using this single-cell technique, 3 test experiments were performed (at $50 \mu \mathrm{E} \mathrm{m} \mathrm{m}^{-2} \mathrm{~s}^{-1}$ ). First, the linearity of ${ }^{14} \mathrm{C}$ uptake over time was tested by incubating tripli- 
cate vials each containing 20 cells for 1, 2, 3, 4, 5, 6 and $7 \mathrm{~h}$. In another test experiment, the results of the single-cell technique were compared with measurements made on whole, undisturbed culture samples to ensure that the cells were not harmed during handling: 4 vials were incubated with $2 \mathrm{ml}$ of light-acclimated Fragilidium subglobosum culture (10 cells ml $\left.{ }^{-1}\right)$, which were gently transferred using an automatic pipette. Another 4 vials each received 20 individually transferred cells. All vials were then incubated and processed as described above. Actively growing cultures of F. subglobosum contain both motile cells and non-motile division cysts (von Stosch 1969, Skovgaard 1996b). Distinguishing between these 2 growth stages when using the single cell technique is difficult and, therefore, a final experiment was run to test whether there was any difference in photosynthetic activity of motile F. subglobosum cells and division cysts. Triplicates of 40 division cysts and 40 motile cells were incubated according to the single-cell technique.

After the test experiments were performed, the single-cell technique was used to determine $P$ (unit: pg C cell ${ }^{-1} \mathrm{~h}^{-1}$ ), for phototrophic (unfed) and mixotrophic (fed) cultures at 4 different irradiances $(25,50,75$ and $150 \mu \mathrm{E} \mathrm{m}^{-2} \mathrm{~s}^{-1}$ ), which were known to support different growth and ingestion rates (Skovgaard 1996a). In addition, $P$ was measured at the light compensation point (7 $\mu \mathrm{E} \mathrm{m}^{-2} \mathrm{~s}^{-1}$, Skovgaard 1996a). For each of the resulting 10 experimental conditions (i.e. 5 irradiances, fed and unfed cells), 12 light- and 4 dark-vials were incubated. Each vial received 40 cells.

Chlorophyll a. Chl a content of Fragilidium subglobosum was determined fluorometrically in cells from the same cultures as used in the photosynthesis experiment: for each irradiance $4 \times 150$ to 350 cells were individually transferred to glass vials and chl a was extracted by adding $4 \mathrm{ml}$ of $96 \%$ ethanol. After $1 \mathrm{~d}$ of storage in darkness at $4^{\circ} \mathrm{C}$, fluorescence was measured with an Aminco JA-7439 Fluoro-Colorimeter and chl a concentrations were calculated according to Parsons et al. (1984).

C and N content. Cellular contents of carbon, C, and nitrogen, $\mathrm{N}$, were determined at each of the 4 above irradiances for Fragilidium subglobosum grown with and without food as well as for Ceratium lineatum. Six F. subglobosum cultures and 3 C. lineatum cultures were acclimated for $>1 \mathrm{wk}$ at each irradiance. Half of the $F$. subglobosum cultures were then fed and incubated for another $\geq 5 \mathrm{~d}$ until all prey cells were ingested. After acclimation, the F. subglobosum cultures were gently retained on a $20 \mu \mathrm{m}$ mesh size net in order to remove smaller particles (bacteria, debris) and the rinsed cultures were then passed through a $100 \mu \mathrm{m}$ mesh size net to remove larger particles (aggregates of shed thecal plates which inevitably accumulate in
F. subglobosum cultures). The fed F. subglobosum cultures were depleted of food $<1 \mathrm{~d}$ prior to harvesting. Finally, the resulting cell suspensions were retained on precombusted GF/C filters after samples had been withdrawn for microscopic determination of cell concentrations. The filters were analyzed with a Control Equipment CHN analyzer. Cell volumes of $F$. subglobosum were determined from linear dimensions of Lugol's fixed cells (final conc.: 1\%). For C. lineatum, cell volumes were calculated on the basis of cingulum widths of Lugol's fixed cells using the regression given by Thomsen (1992).

\section{RESULTS}

\section{Methodology}

By using the single-cell ${ }^{14} \mathrm{C}$ uptake technique it was possible not only to prevent interference from prey photosynthesis but also to obtain reliable measurements of photosynthesis $(P)$ using a few cells even at low irradiances. The ${ }^{14} \mathrm{C}$ uptake was linear for at least the first $5 \mathrm{~h}$ of incubation for both unfed and fed cells (Fig. 1), and an incubation time of $3 \mathrm{~h}$ was selected for further experiments. The uptake of ${ }^{14} \mathrm{C}$ in light-vials was for all incubations $>4 \times$ the uptake in dark-vials (data not shown). There was no difference between $P$ of cells which had been individually transferred with a micropipette and cells which were incubated in the unmanipulated cell suspension (Fig. 2). Also, $P$ of motile cells did not differ significantly from that of division cysts (Fig. 2, $t$-test, $\mathrm{p}>0.05$ ), even though there

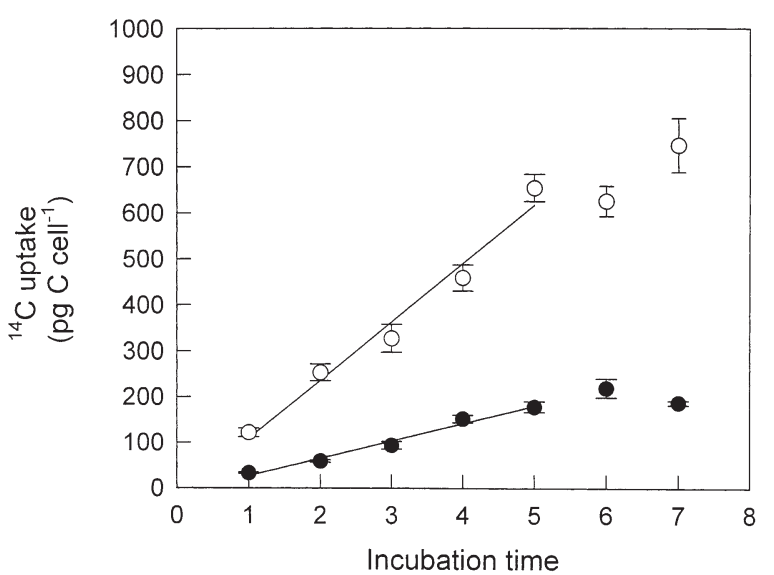

(h)

Fig. 1. Fragilidium subglobosum photosynthesis. Uptake of ${ }^{14} \mathrm{C}$ as a function of duration of incubation period for unfed $(\mathrm{O})$ and fed $(\bullet)$ cells at $50 \mu \mathrm{E} \mathrm{m} \mathrm{m}^{-2} \mathrm{~s}^{-1}$. Lines represent linear regressions of the first 5 data points of each data set. Error bars $= \pm 1 \mathrm{SE}, \mathrm{r}^{2}=0.98$ for both regressions 


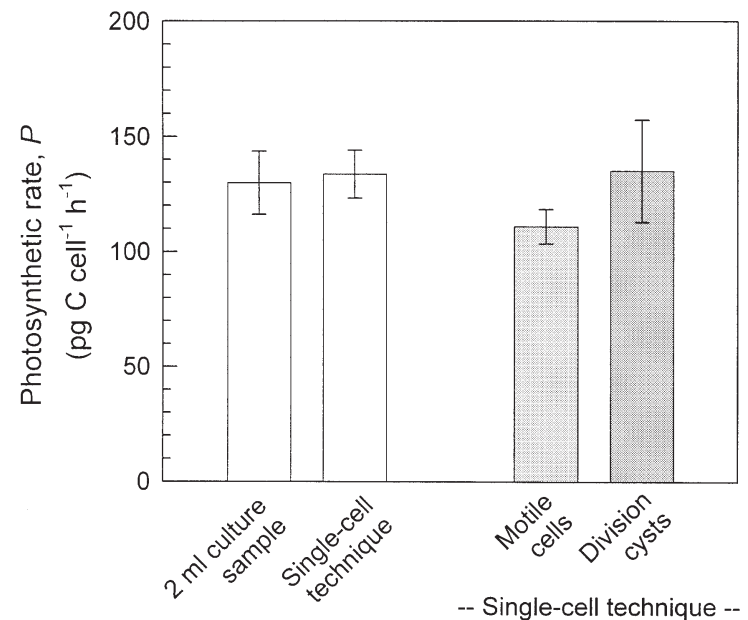

Fig. 2. Comparison of different protocols for measuring photosynthetic rates of Fragilidium subglobosum using the ${ }^{14} \mathrm{C}$ technique. Open bars: unmanipulated culture sample versus single-cell technique. Shaded bars: motile cells versus division cysts, both measured with the single-cell ${ }^{14} \mathrm{C}$ technique. Error bars $= \pm 1 \mathrm{SE}$

was a tendency of slightly higher $P$ for division cysts than for motile cells. This tendency was probably due to a potential larger average size for division cysts than for motile cells (data not shown), and in subsequent experiments efforts were made to use cells of approximately equal size rather than distinguishing between the 2 growth stages.

\section{Photosynthesis and chl a}

The $P$ of unfed Fragilidium subglobosum cells increased with increasing irradiance (Fig. 3), reaching

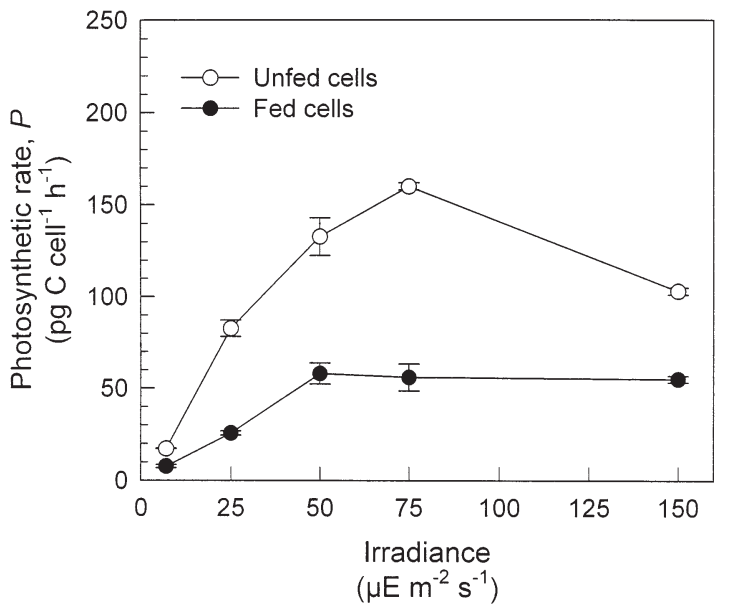

Fig. 3. Fragilidium subglobosum. Photosynthetic rates $(P)$ in phototrophic (unfed) cultures and in mixotrophic cultures (fed Ceratium lineatum) at different irradiances. Error bars $= \pm 1 \mathrm{SE}$

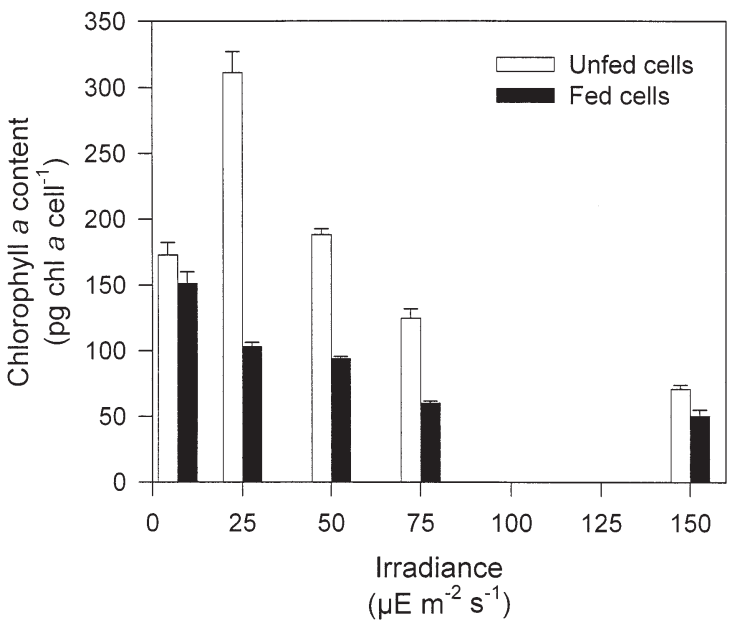

Fig. 4. Fragilidium subglobosum. Chl a content of cells grown in phototrophic (unfed) cultures and in mixotrophic cultures (fed Ceratium lineatum) at different irradiances. F. subglobosum cells were isolated from the prey prior to fluorometric chl a determination. Error bars $= \pm 1 \mathrm{SE}$

$160 \pm 8($ mean $\pm \mathrm{SE})$ pg $\mathrm{C}$ cell $^{-1} \mathrm{~h}^{-1}$ at $75 \mu \mathrm{E} \mathrm{m} \mathrm{m}^{-2} \mathrm{~s}^{-1}$. Above this point, $P$ decreased to $103 \pm 2 \mathrm{pg} \mathrm{Cell}^{-1} \mathrm{~h}^{-1}$. At the phototrophic light compensation point $(\sim 7 \mu \mathrm{E}$ $\left.\mathrm{m}^{-2} \mathrm{~s}^{-1}\right), P$ was $17 \pm 0.2 \mathrm{pg} \mathrm{C}$ cell ${ }^{-1} \mathrm{~h}^{-1}$ for unfed cells. In phototrophic cultures, the basal need of $\mathrm{C}$ in order to keep population size constant was thus $276 \mathrm{pg} \mathrm{C}$ cell $^{-1}$ $\mathrm{d}^{-1}\left(16 \mathrm{~h}\right.$ light $\left.\mathrm{d}^{-1}\right)$. For fed cells, $P$ was $8 \pm 0.9 \mathrm{pg} \mathrm{C}$ cell $^{-1} \mathrm{~h}^{-1}$ at the light compensation point. At higher irradiances, $P$ ranged from 26 to $58 \mathrm{pg} \mathrm{C}$ cell $^{-1} \mathrm{~h}^{-1}$ for fed cells and was thus markedly reduced in relation to $P$ for unfed cells. This phagotrophically induced reduction in $P$ ranged from 47 to $69 \%$ and showed little dependence on irradiance (Fig. 3).

Chl a content was highly dependent on light and generally decreased with increasing irradiance: in phototrophically grown (unfed) cultures cellular chl a content decreased from 311 to $71 \mathrm{pg}$ chl a cell ${ }^{-1}$ over the range of 25 to $150 \mu \mathrm{E} \mathrm{m}^{-2} \mathrm{~s}^{-1}$ (Fig. 4). In mixotrophic (fed) cultures cellular chl a content was more constant, but decreased from 103 to $50 \mathrm{pg}$ chl a cell-1 over the same irradiance range (Fig. 4). Reduction in cellular chl a content due to phagotrophic activity ranged from 29 to $67 \%$. At the phototrophic light compensation point, cellular chl a content was as low as $173 \mathrm{pg}$ chl a cell $^{-1}$ in unfed cells, and the reduction in chl a due to phagotrophy was only $13 \%$.

By regarding the chl a-normalized photosynthetic rate $\left(P^{*}\right)$ as a function of irradiance, possible effects of cell size and cellular chl a content on $P$ are eliminated. For both unfed and fed cells, $P^{*}$ increased over the entire irradiance range investigated (Fig. 5). As in the case for $P$, phagotrophy decreased $P^{*}$; however, the reduction in $P^{*}$ was less pronounced ( 7 to $28 \%$ ) than 
the reduction in $P$ (47 to $69 \%$ ) except at the phototrophic light compensation point, where the reduction in $P^{*}$ was $49 \%$, compared to $56 \%$ for $P$.

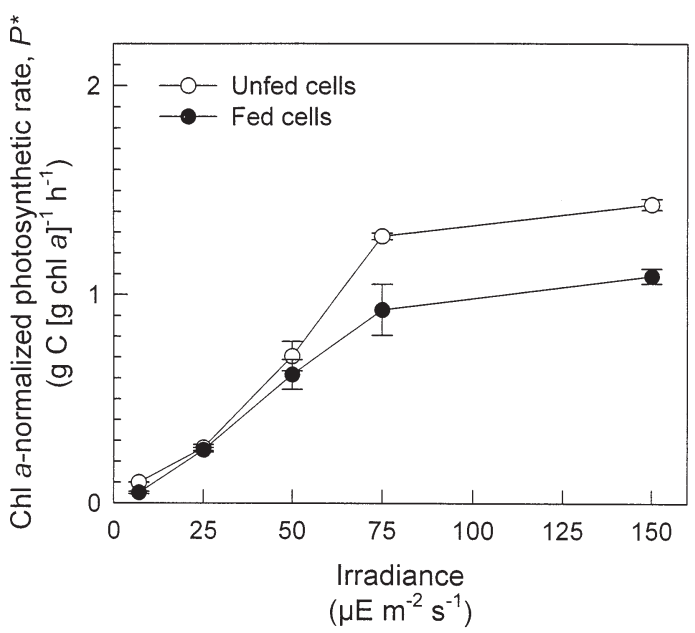

Fig. 5. Fragilidium subglobosum. Chl a-normalized photosynthetic rates $\left(P^{*}\right)$ in phototrophic (unfed) cultures and in mixotrophic cultures (fed Ceratium lineatum) at different irradiances. Error bars $= \pm 1 \mathrm{SE}$

\section{Gross carbon budget}

Table 1 summarizes the contents of $\mathrm{C}$ and $\mathrm{N}$ and cell volumes of unfed and fed Fragilidium subglobosum cells as well as of prey cells. Overall, $\mathrm{C}$ and $\mathrm{N}$ contents of F. subglobosum were proportional to cell volume, and the large size of unfed cells grown at low irradiance $\left(25 \mu \mathrm{E} \mathrm{m} \mathrm{m}^{-2} \mathrm{~s}^{-1}\right)$ was thus reflected in corresponding elevations in $\mathrm{C}$ and $\mathrm{N}$ contents. Ceratium lineatum cells, on the contrary, had a higher average C:volume ratio $\left(0.25 \mathrm{pg} \mathrm{C} \mathrm{um}^{-3}\right)$ at the highest irradiance as compared with the 3 lower ones $(0.18$ to $0.20 \mathrm{pg} \mathrm{C}$ $\mu^{-3}$ ). A similar pattern was present for the N:volume ratio of $C$. lineatum. In addition, mean cell volume of $C$. lineatum was larger at the highest and lowest irradiances (25 and $150 \mu \mathrm{E} \mathrm{m} \mathrm{m}^{-2} \mathrm{~s}^{-1}$ ) as compared with the intermediate irradiances.

In general, food uptake by far contributed the most to total uptake of $\mathrm{C}$ by fed Fragilidium subglobosum cells when food was plentiful (Fig. 6A, derived from Skovgaard 1996a, and Table 1), and the phagotrophic uptake of $\mathrm{C}$ and $\mathrm{N}$ showed little dependence on irradiance. On a daily basis, the contribution of food uptake to the gross (ingestion and photosynthesis) C uptake

Table 1. C and N contents and volumes at different irradiances of Fragilidium subglobosum cells cultured with and without prey and of prey cells, Ceratium lineatum. Numbers represent means $\pm 1 \mathrm{SE}, \mathrm{n}=3$ (for cell volumes $\mathrm{n}=100$ )

\begin{tabular}{|c|c|c|c|c|}
\hline & \multicolumn{4}{|c|}{$\begin{array}{c}\text { Irradiance } \\
\left(\mu \mathrm{mol} \text { photons } \mathrm{m}^{-2} \mathrm{~s}^{-1}\right)\end{array}$} \\
\hline & 25 & 50 & 75 & 150 \\
\hline \multicolumn{5}{|l|}{$\mathrm{C}$ content (ng $\mathbf{C}$ cell $^{-1}$ ) } \\
\hline F. subglobosum unfed & $13.5 \pm 1.1$ & $8.0 \pm 1.0$ & $7.6 \pm 0.5$ & $5.9 \pm 0.4$ \\
\hline F. subglobosum fed & $7.7 \pm 0.4$ & $7.6 \pm 0.5$ & $5.9 \pm 0.3$ & $7.5 \pm 0.4$ \\
\hline C. lineatum & $1.6 \pm 0.1$ & $1.2 \pm 0.1$ & $1.3 \pm 0.2$ & $1.9 \pm 0.3$ \\
\hline \multicolumn{5}{|l|}{$\mathrm{N}$ content $\left(\mathrm{ng} \mathrm{N} \mathrm{cell}^{-1}\right)$} \\
\hline F. subglobosum unfed & $2.9 \pm 0.3$ & $1.3 \pm 0.1$ & $1.5 \pm 0.1$ & $1.0 \pm 0.1$ \\
\hline F. subglobosum fed & $1.6 \pm 0.1$ & $1.5 \pm 0.1$ & $1.3 \pm 0.1$ & $1.3 \pm 0.1$ \\
\hline C. lineatum & $0.28 \pm 0.02$ & $0.19 \pm 0.02$ & $0.21 \pm 0.02$ & $0.31 \pm 0.05$ \\
\hline \multicolumn{5}{|l|}{ Cell volume $\left(\times 10^{3} \mu^{3}\right)$} \\
\hline F. subglobosum unfed & $72.6 \pm 2.8$ & $39.6 \pm 2.0$ & $42.9 \pm 1.5$ & $35.2 \pm 2.0$ \\
\hline F. subglobosum fed & $47.3 \pm 1.8$ & $38.6 \pm 1.6$ & $42.3 \pm 1.9$ & $43.2 \pm 1.5$ \\
\hline C. lineatum ${ }^{\mathrm{a}}$ & $8.8 \pm 0.2$ & $6.4 \pm 0.1$ & $6.8 \pm 0.2$ & $7.4 \pm 0.2$ \\
\hline \multicolumn{5}{|l|}{ C:volume ratio (pg C $\mu^{-3}$ ) } \\
\hline F. subglobosum unfed & 0.19 & 0.20 & 0.18 & 0.17 \\
\hline F. subglobosum fed & 0.16 & 0.20 & 0.14 & 0.17 \\
\hline C. lineatum & 0.18 & 0.19 & 0.20 & 0.25 \\
\hline \multicolumn{5}{|l|}{ C:chl a ratio (g C $[g \text { chl } a]^{-1}$ ) } \\
\hline F. subglobosum unfed & 43.2 & 42.4 & 60.9 & 83.4 \\
\hline F. subglobosum fed & 74.6 & 81.3 & 98.0 & 148.1 \\
\hline \multicolumn{5}{|l|}{$\mathrm{N}$ :volume ratio $\left(\mathrm{pg} N \mathrm{\mu m}^{-3}\right.$ ) } \\
\hline F. subglobosum unfed & 0.039 & 0.032 & 0.034 & 0.027 \\
\hline F. subglobosum fed & 0.034 & 0.038 & 0.030 & 0.030 \\
\hline C. lineatum & 0.032 & 0.030 & 0.031 & 0.042 \\
\hline
\end{tabular}



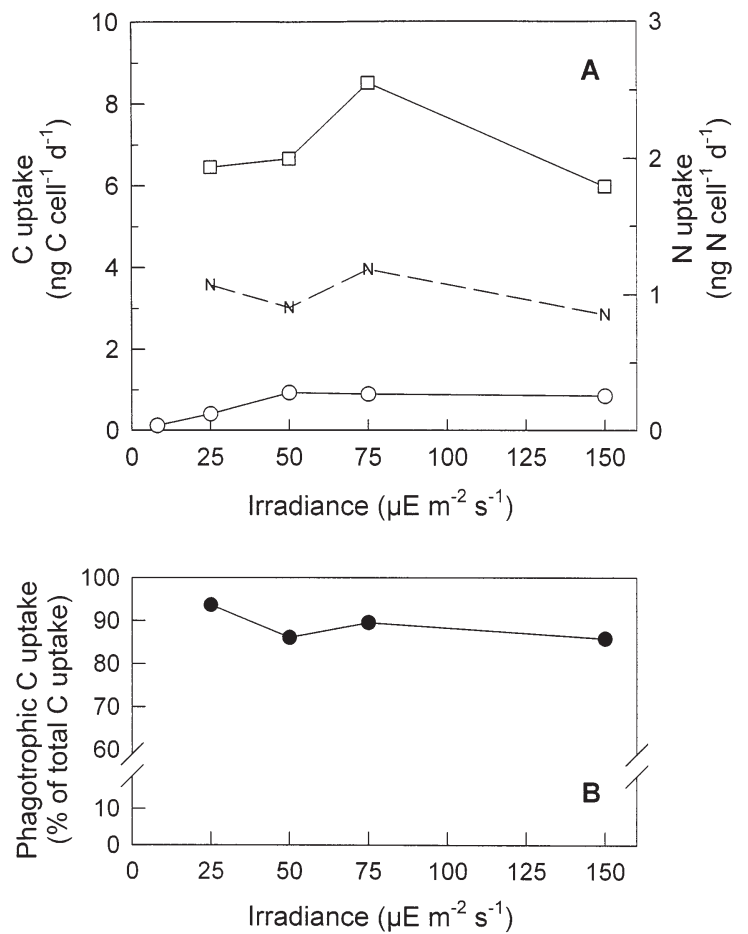

Fig. 6. Fragilidium subglobosum. Estimated daily gross C budget in mixotrophic cultures (fed Ceratium lineatum) at different irradiances. (A) Amount C (ㅁ) and N (N) acquired through ingestion of food (including unassimilated fraction) and amount of $\mathrm{C}$ acquired through photosynthesis (O). (B) Relative proportion of carbon uptake acquired through food uptake (•)

(Fig. 6B) was 86 to $94 \%$. It is important to note, however, that the proportion of ingested $\mathrm{C}$ that was digested and assimilated is not considered here.

The C:chl a ratio for unfed Fragilidium subglobosum cells was 42.4 to $83.4 \mathrm{~g} \mathrm{C}$ ( $\mathrm{g} \mathrm{chl} \mathrm{a)^{-1 }}$, but considerably higher for fed cells, 74.6 to $148.1 \mathrm{~g} \mathrm{C} \mathrm{(g} \mathrm{chl} \mathrm{a})^{-1}$ (Table 1). The C:chl a ratios of both unfed and fed cells were positively correlated with irradiance.

\section{DISCUSSION}

\section{Photosynthesis and chl a}

The $P$ of unfed Fragilidium subglobosum cells was higher at 75 than at 50 or $150 \mu \mathrm{E} \mathrm{m}^{-2} \mathrm{~s}^{-1}$, suggesting that photosynthesis is saturated at irradiances $<150 \mu \mathrm{E}$ $\mathrm{m}^{-2} \mathrm{~s}^{-1}$. This may seem inconsistent with the fact that phototrophic growth rate of $F$. subglobosum has its

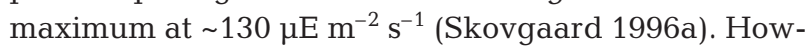
ever, both size and C content of F. subglobosum cells growing without food are reduced with increasing irradiance (Skovgaard 1996a) and, therefore, cell-specific
$P$ does not necessarily correlate with the rate of increase in cell number. In fact, maximum $P^{*}$ was measured at $150 \mu \mathrm{E} \mathrm{m}^{-2} \mathrm{~s}^{-1}$ (Fig. 5).

This study confirms the hypothesis that photosynthesis is reduced by phagotrophy in Fragilidium subglobosum. This finding is consistent with the fact that cellular chl a content is decreased due to phagotrophy (Fig. 4, Skovgaard 1996a). However, chl a content is not necessarily correlated with photosynthetic rate (Holen \& Boraas 1995) and phagotrophy does not always reduce photosynthesis. In another mixotrophic dinoflagellate, Gymnodinium galatheanum, photosynthesis actually seems to be stimulated by feeding (Li et al. 1999).

Since phagotrophy in general has a greater reducing effect on $P$ than on chl a content in Fragilidium subglobosum, $P^{*}$ is also negatively affected by food uptake. It may, therefore, seem that not only is the photosynthetic apparatus of mixotrophically growing cells reduced quantitatively in terms of reduced chl a content, it is also reduced qualitatively, i.e. the efficiency of the (remaining) photosynthetic apparatus is reduced. An explanation could be that chloroplasts in fed cells are masked by food vacuoles. However, since food is accumulated in the centre of the cell (Skovgaard 1996b), masking of the peripheral chloroplasts is not likely to be pronounced. Fed cells may also contain undigested prey chl $a$, which is probably photosynthetically inactive, and this could explain at least some of the decrease in $P^{*}$ in fed cells. It is also possible that a part of this apparent loss in efficiency is an artifact caused by lower measured photosynthesis due to an elevated level of recycling of inorganic $\mathrm{C}$ in phagotrophically active cells (i.e. due to respiration of $\mathrm{C}$ acquired through ingestion of food). This hypothesis is investigated in more detail in the following paper (Hansen et al. 2000).

\section{Gross carbon budget}

In Skovgaard (1996a) it was shown that the ingestion rate of Fragilidium subglobosum in food-satiated cultures was dependent on irradiance, and this was supported by the findings of Hansen \& Nielsen (1997). By combining these ingestion rates with the present measured cellular $\mathrm{C}$ and $\mathrm{N}$ contents, it is revealed that the total daily uptake of $\mathrm{C}$ and $\mathrm{N}$ through phagotrophy shows only little dependence on irradiance, because lower ingestion rates in terms of numbers of prey cells ingested per day are counterbalanced by differences in prey cell size and $\mathrm{C}$ and $\mathrm{N}$ :volume ratios of the prey (Fig. 6A). In the present study, total $\mathrm{C}$ uptake was measured at only a few irradiances, but it is not likely that the determination of total $\mathrm{C}$ uptake 
versus irradiancy in more details would yield larger variations, since the irradiances chosen here have previously been shown to support the most extreme ingestion rates (Skovgaard 1996a). It therefore seems that $\mathrm{C}$-specific ingestion rates of $F$. subglobosum in food-satiated cultures is not affected as much by irradiance as previously thought. What governs the different ingestion rates in terms of number of prey cells ingested per day (Skovgaard 1996a) may not be irradiance directly, but rather the $\mathrm{C}$ content of the prey, which is in turn affected by irradiance. These results emphasize the importance of taking $\mathrm{C}$ content of prey cells into account when studying protist food uptake, particularly when the food organisms are grown under different light conditions. This point should be kept in mind when interpreting earlier studies of food uptake in mixotrophs (e.g. Jones et al. 1993, Hansen \& Nielsen 1997, Skovgaard 1998, Jeong et al. 1999, Li et al. 1999).

Ingested carbon and photosynthate probably differ in the efficiency and pathways by which they are metabolized by a mixotroph and may have different fates within a cell. In some mixotrophs, for example, photosynthate is preferentially respired over carbon derived form feeding (Putt 1990). Ingested food must be digested and assimilated before it can be utilized by a cell, and digestion (assimilation) efficiencies in phagotrophic protists are thought to range from about 22 to $76 \%$ (Laybourn-Parry 1992). For photosynthate, digestion is presumably not an issue. Since photosynthate consists of relatively simple carbon compounds (e.g. Raven 1974), it is plausible that these compounds are more readily utilized as a source for respiration and growth than more complex organic compounds obtained through feeding. For these reasons, even though gross carbon uptake of Fragilidium subglobosum in mixotrophic cultures is dominated by phagotrophy (Fig. 6), it does not necessarily follow that phagotrophy contributes the same large proportion of carbon to the cell's metabolism or to the production of new $F$. subglobosum biomass. This matter is dealt with in more detail in Hansen et al. (2000).

The role of mixotrophy in dinoflagellate field populations is still in need of being investigated. This study shows that phagotrophy can be an important factor in the carbon metabolism of a dinoflagellate population under laboratory conditions. The determination of photosynthetic rates alone would, therefore, have severely underestimated the actual dinoflagellate production rate. Similar physiological characteristics may occur in natural dinoflagellate populations and partial phagotrophic nutrition could in fact explain the unusually low production:respiration ratio found during some dinoflagellate blooms (Garcia \& Purdie 1994).
Acknowledgements. For this study A.S. was supported by a $\mathrm{PhD}$ grant from The University of Copenhagen, P.J.H. was funded by the Danish Natural Research Council project no. 950263-28808 and D.K.S. was partially supported by NSF grant OCE-9819670.

\section{LITERATURE CITED}

Andersson A, Falk S, Samuelsson G, Hagström ^̊ (1989) Nutritional characteristics of a mixotrophic nanoflagellates, Ochromonas sp. Microb Ecol 14:251-262

Bird DF, Kalff J (1986) Bacterial grazing by planktonic lake algae. Science 231:493-495

Bird DF, Kalff J (1987) Algal phagotrophy: regulating factors and importance relative to photosynthesis in Dinobryon (Chrysophyceae). Limnol Oceanogr 32:277-284

Bockstahler KR, Coats DW (1993) Spatial and temporal aspects of mixotrophy in Chesapeake Bay dinoflagellates. J Eukaryot Microbiol 40:49-60

Caron DA, Porter KG, Sanders RW (1990) Carbon, nitrogen, and phosphorus budgets for the mixotrophic phytoflagellate Poterioochromonas malhamensis (Chrysophyceae) during bacterial ingestion. Limnol Oceanogr 35:433-443

Caron DA, Sanders RW, Lim EL, Marrasé C, Amaral LA, Whitney S, Aoki RB, Porter KG (1993) Light-dependent phagotrophy in the freshwater mixotrophic chrysophyte Dinobryon cylindricum. Microb Ecol 25:93-111

Garcia VMT, Purdie DA (1994) Primary production studies during a Gyrodinium cf. aureolum (Dinophyceae) bloom in the western English Channel. Mar Biol 119:297-305

Hall JA, Barret DP, James MR (1993) The importance of phytoflagellates, heterotrophic flagellate and ciliate grazing on bacteria and picophytoplankton sized prey in a coastal marine environment. J Plankton Res 15:1075-1086

Hansen PJ (1989) The red tide dinoflagellate Alexandrium tamarense: effects on behaviour and growth of a tintinnid ciliate. Mar Ecol Prog Ser 53:105-116

Hansen PJ, Nielsen TG (1997) Mixotrophic feeding of Fragilidium subglobosum (Dinophyceae) on three species of Ceratium: effects of prey concentration, prey species and light intensity. Mar Ecol Prog Ser 147:187-196

Hansen PJ, Skovgaard A, Glud RN, Stoecker DK (2000) Physiology of the mixotrophic dinoflagellate Fragilidium subglobosum. II. Effects of time scale and prey concentration on photosynthetic performance. Mar Ecol Prog Ser 201: 137-146

Holen DA, Boraas ME (1995) Mixotrophy in chrysophytes. In: Sandgren CD, Smol JP, Kristiansen J (eds) Chrysophyte algae; ecology, phylogeny and development. Cambridge University Press, Cambridge, p 119-140

Jeong HJ, Shim JH, Kim JS, Park JY, Lee CW, Lee Y (1999) Feeding by the mixotrophic thecate dinoflagellate Fragilidium cf. mexicanum on red-tide and toxic dinoflagellates. Mar Ecol Prog Ser 176:263-277

Jones HLJ, Leadbeater BSC, Green JC (1993) Mixotrophy in marine species of Chrysochromulina (Prymnesiophyceae): ingestion and digestion of a small green flagellate. J Mar Biol Assoc UK 73:283-296

Jones HLJ, Durjun P, Leadbeater BSC, Green JC (1995) The relationship between photoacclimation and phagotrophy with respect to chlorophyll $a$, carbon and nitrogen content, and cell size of Chrysochromulina brevifilum (Prymnesiophyceae). Phycologia 34:128-134

Laybourn-Parry J (1992) Protozoan plankton ecology. Chapman \& Hall, London

Li A, Stoecker DK, Adolf JE (1999) Feeding, pigmentation, 
photosynthesis and growth of the mixotrophic dinoflagellate Gyrodinium galatheanum. Aquat Microb Ecol 19: 163-176

Parsons TR, Maita Y, Lalli CM (1984) A manual of chemical and biological methods for seawater analysis. Pergamon Press, Oxford

Putt M (1990) Metabolism of photosynthate in the chloroplastretaining ciliate Laboea strobila. Mar Ecol Prog Ser 60: 271-282

Raven JA (1974) Carbon dioxide fixation. In: Stewart WDP (ed) Algal physiology and biochemistry. Botanical Monographs, Vol 10. Blackwell Scientific Publications, Oxford, p 434-455

Rivkin RB, Seliger HH (1981) Liquid scintillation counting for ${ }^{14} \mathrm{C}$ uptake of single algal cells isolated from natural samples. Limnol Oceanogr 26:780-785

Sanders RW, Porter KG, Bennett SJ (1989) Seasonal patterns of bacterivory by flagellates, ciliates, rotifers, and cladocerans in a freshwater planktonic community. Limnol Oceanogr 34:673-687

Sanders RW, Porter KG, Caron DA (1990) Relationship between phototrophy and phagotrophy in the mixotrophic

Editorial responsibility: John Austin (Assistant Editor), Oldendorf/Luhe, Germany chrysophyte Poterioochromonas malhamensis. Microb Ecol 19:97-109

Skovgaard A (1996a) Mixotrophy in Fragilidium subglobosum (Dinophyceae): growth and grazing responses as functions of light intensity. Mar Ecol Prog Ser 143:247-253

Skovgaard A (1996b) Engulfment of Ceratium spp. (Dinophyceae) by the thecate photosynthetic dinoflagellate Fragilidium subglobosum. Phycologia 35:490-499

Skovgaard A (1998) Role of chloroplast retention in a marine dinoflagellate. Aquat Microb Ecol 15:293-301

Stoecker DK, Silver MW, Michaels AE, Davis LH (1988) Obligate mixotrophy in Laboea strobila, a ciliate which retains chloroplasts. Mar Biol 99:415-423

Stoecker DK, Li A, Coats DW, Gustafson DE, Nannen MK (1997) Mixotrophy in the dinoflagellate Prorocentrum minimum. Mar Ecol Prog Ser 152:1-12

Thomsen HA (1992) Plankton i de indre danske farvande. Havforskning fra Miljøstyrelsen, No. 11. The Danish Environmental Protection Agency, Copenhagen

von Stosch HA (1969) Dinoflagellaten aus der Nordsee. II. Helgolandinium subglobosum gen. et spec. nov. Helgol Wiss Meeresunters 19:569-577

Submitted: June 24, 1999; Accepted: February 8, 2000 Proofs received from author(s): June 29, 2000 